\title{
Healthcare in crisis: A shameful disrespect of our Constitution
}

\author{
A Dhai, ${ }^{1}$ PhD, MB ChB, FCOG, LLM, PGDip Int Res Ethics; S Mahomed, ${ }^{2}$ BCom, LLB, LLM, PhD \\ 'Steve Biko Centre for Bioethics, Faculty of Health Sciences, University of the Witwatersrand, Johannesburg, South Africa \\ ${ }^{2}$ School of Law, College of Law, University of South Africa, Pretoria, South Africa
}

Corresponding author: A Dhai (ames.dhai@wits.ac.za)

\begin{abstract}
Healthcare in South Africa (SA) is in crisis. Of the complaints received by the health ombud, $40 \%$ are from Gauteng Province. Despite the dire shortage of human resources, the Gauteng Department of Health has decided not to fill vacated posts. As a result, the training of registrars and medical students suffers. Legal constraints have also created an impasse between tiers of government, allowing for near self-governance with impunity at the provincial offices. The public sector provides healthcare access to $84 \%$ of patients in SA, and this group is being denied access to healthcare in the country. The fundamental right to healthcare is affirmed in the Constitution; however, its implementation is riddled with impediments. Urgent intervention is necessary to address the crisis.
\end{abstract}

S Afr J Bioethics Law 2018;11(1):8-10. DOI:10.7196/SAJBL.2018.v11i1.649

In the wake of the Life Esidimeni tragedy Arbitration, Prof. Malegapuru Makgoba, the South African (SA) health ombud, on 4 June 2018, expressed his concerns on 'The Modise Network' that SA's public healthcare system was on the verge of collapse. Since his appointment in 2016, he had received over 2000 complaints, of which 40\% were from Gauteng Province. ${ }^{[1]}$ The Minister of Health, Dr Aaron Motsoaledi, subsequently acknowledged that the healthcare system was 'very distressed.' While attributing this 'distress' to the exponential growth of the burden of disease, he also acknowledged that management skills in most of the hospitals were poor, and stated that at that time, 200 officials had been sent from the department's head office to assist with management issues. He confirmed that there also were many other problems, including overcrowding, long waiting lists for treatment, irregular buying of goods, poor financial management and a chronic shortage of human resources. ${ }^{[2]}$

Despite the dire human resources situation, the Gauteng Department of Health has decided not to fill posts once they have been vacated. The SA Committee of Medical Deans has expressed concerns that posts have been frozen by the department because it is cash-strapped. This means that fewer specialists-in-training (registrars) will be employed after they qualify. A further concern is that specialists are not replaced in vacant posts created by resignations or retirements. Thus too few teachers are left to train registrars and medical students. Dr Motsoaledi has expressed his anxiety about the three training centres in Gauteng losing training capacity, which is particularly concerning because Gauteng trains the largest number of doctors in Africa. He stated that he would impress on the province the need to fill its posts, but unfortunately, he has no power over provinces because of legal constraints ${ }^{[3]}$ This is because legislation has created an impasse between tiers of government, allowing for near self-governance with impunity at the level of provincial offices.

Because of salary disputes, non-payment of bonuses and lack of salary increases, the National Education, Health and Allied Workers'
Union (NEHAWU) embarked on strike action in the healthcare sectors in the North West and Gauteng provinces, despite this not being compliant with the Labour Relations Act No. 66 of 1995. They stopped providing services, prevented patients from entering hospitals, closed medicine depots, trashed hospital corridors, erected burning barriers outside hospitals, stoned vehicles including ambulances and threatened or otherwise prevented healthcare professionals from treating patients. Security personnel and even the police were reluctant to intervene. ${ }^{[4,5]}$

Of all patients in SA, 84\% access healthcare in the public sector, ${ }^{[6]}$ which this group is being denied. In the main, they are SA's most vulnerable poor. They are the victims of failing leadership, incompetent management, poor governance, legislative constraints and strikes amongst workers in essential services. They are forced to bear the associated burdens of morbidity and mortality. Poor people are more vulnerable than others to a range of illnesses, and may also experience poor healthcare because of a lack of access. ${ }^{[7]}$ This vulnerability is further heightened by institutional and functional failures that further impede access.

SA's healthcare is clearly in intensive care, and urgently needs rigorous resuscitation. We review the right to healthcare in the context of international and regional human rights instruments, and discuss relevant laws and the SA Constitution. Specific reference is made to the Gauteng Department of Health, because most of the complaints received by the health ombud come from this province, and it trains the largest number of doctors in Africa.

\section{The right to health - international instruments}

The right to health is enshrined in the Universal Declaration of Human Rights, several international treatises and the Constitution of the World Health Organization (WHO). This right was first articulated in 1946, in the WHO's Constitution, the preamble of which states that 
'the enjoyment of the highest attainable standard of health is one of the fundamental rights of every human being, without distinction of race, religion, political belief, economic or social condition. ${ }^{[8]}$ Health was included as an aspect of the right to an adequate standard of living in the 1948 Universal Declaration of Human Rights. ${ }^{[9]}$ The International Covenant on Economic, Social and Cultural Rights of 1966 is widely considered as the cornerstone of international human rights law, in terms of the protection of the right to health. It affirms the 'right of everyone to the enjoyment of the highest attainable standard of physical and mental health., ${ }^{\text {[10] }}$ This is similar to the statement in the WHO Constitution. The right to health is also established regionally in the African Charter on Human and People's Rights (the Banjul Charter). ${ }^{[11]}$

Freedoms and entitlements are embedded in the right to health. Freedoms include informed choice. The provision of equal opportunities for everyone to enjoy the highest attainable level of health is a constitutionally safeguarded entitlement. The right to health refers to the 'right to the enjoyment of a variety of goods, facilities, services and conditions necessary for its realisation.'[12] Despite the notion of 'highest attainable standard' being decreed by international human rights law, it lacks direction on its meaning and attainment. This deficiency in specificity and enforcement are major gaps in achieving health rights on the ground. Within their available resources, member states are free to make determinations on its progressive realisation. Without any tangible obligation, a default position of not realising the right to health because of resource constraints could ensue. This is the situation that has arisen at the level of the provincial offices in SA.

\section{The SA Constitutional right to healthcare}

Section 27 of the Bill of Rights of the Constitution of the Republic of $\mathrm{SA}^{[13]}$ affirms everyone's right to access to healthcare services, including reproductive healthcare. Within its available resources, the state has an obligation to take reasonable legislative and other measures to achieve the progressive realisation of this right. The Bill of Rights also establishes that no one may be refused emergency medical treatment. Legislative and policy measures towards SA's Constitutional mandate on the progressive realisation of health include the National Health Act No. 61 of $2003(\mathrm{NHA})^{[14]}$ and the Patients' Rights Charter. ${ }^{[15]}$ The NHA serves to provide a uniform framework for a structured health system in the country. It recognises the socioeconomic injustices, imbalances and inequities of the past, and the need to improve the quality of life of all citizens and free the potential of each person in the country.

Regarding children, section 28 of the Constitution affirms every child's right to healthcare services, but unlike section 27, contains no qualification based on available resources for its progressive realisation. It defines a child as a person under the age of eighteen, and states that in every matter concerning the child, his or her best interests are of paramount importance. The Children's Act No. 38 of $2005^{[16]}$ enacts certain rights of children, as stipulated in the Constitution. Similarly to the NHA, it promises to improve quality of life and free each person's potential. However, it also underscores the need to extend particular care to children, as decreed in several international human rights instruments, including the Geneva Declaration of the Rights of the Child, the United Nations Declaration on the Rights of the Child, the Convention on the Rights of the Child, the Universal Declaration of Human Rights and the African Charter on the Rights and Welfare of the Child.

The right to healthcare is closely linked to the Constitutional rights to life (section 11) and dignity (section 10), because not obtaining necessary treatment could result in grave morbidity impacting dignity, or in death. Lack of access to healthcare has resulted in the death of 144 patients, as evidenced in the Life Esidimeni tragedy Arbitration. ${ }^{[17]}$ Justice Dikgang Moseneke stated during the hearings that the right to human dignity is 'critical to a meaningful departure from the oppression of the apartheid era. Colonialism and apartheid were the antithesis of human dignity. The recognition of the self-worth of each individual, regardless of their circumstances, is a prerequisite to the achievement of our constitutional values, and therefore our democratic project. ${ }^{[17]}$

Several non-derogable rights, including the extents to which these are protected, are listed in the Constitution. The rights to life and dignity are entirely non-derogable. With access to healthcare being denied to many of our country's patients, the impact of violating health access on two fundamental non-derogable rights creates a grave situation.

\section{The duties imposed by the Constitution}

As stated in the Life Esidimeni Arbitration Report, ${ }_{1}^{[17]}$ the Constitution is binding on all organs of state and every state official entrusted with public power. Section 8 (1) states that 'the Bill of Rights applies to all law, and binds the legislature, the executive, the judiciary and all organs of state.'The Constitution imposes overarching duties on those delegated to exercise public power. Essential to this is the need to be faithful to the law. Public officials must act within the constraints of the law, and avoid unlawful conduct. The founding values of openness, responsiveness and accountability in the exercise of public power that affects all people in the country are embedded in the Constitution's democratic practices. ${ }^{[17]}$ The Constitution sets high values and principles for officials in the public service and public administration must respect these, including holding to 'a high standard of professional ethics, using public resources in an efficient, economic and effective manner, providing services impartially, fairly, equitably, and without bias, and being responsive to people's needs. ${ }^{[17]}$ Schedule 2, section 5 of the Constitution ${ }^{[13]}$ requires the provincial premiers and members of the executive councils to swear an oath or take a solemn affirmation to be faithful to the country and uphold the Constitution and all other laws, and to undertake to hold one's office with honour and dignity, and to perform the functions of one's office conscientiously and to the best of one's ability.

\section{The legal bottleneck}

According to section 104 of the Constitution, provincial authority includes the power to legislate with regard to any Schedule 4 matter, including health services, as a concurrent competency. However, where there is a conflict between national legislation and a provision of a provincial constitution with regard to a Schedule 4 matter, then national legislation applies, subject to specific conditions (section 147(1)(c) read with section 146 of the Constitution). National legislation that applies uniformly to the whole country will prevail over provincial legislature where the national legislation is necessary to promote equal access to government services (section $146(2)(c)$ ). National legislation will also prevail over provincial legislation where 
the national legislation is aimed at preventing unreasonable action by a province that is prejudicial to the health interests of the country as a whole (section 146(3)(a) Constitution). The NHA provides specific roles and functions for national (section 3 ) and provincial (section 25) government. Provincial governments are empowered to develop and implement policy, removing the need for centrality of power.

\section{Conclusion}

Freezing posts to address the poor financial management that has resulted in healthcare being in distress is not being responsive to the needs of patients; it further intensifies their suffering. It also demonstrates the inability of hospital management to respond to patients' needs fairly and effectively. Clinics and surgical slates being cancelled, longer waiting times, increasing morbidity and mortality and increasing adverse events, resulting in a worsening of the country's medicolegal storm, illustrate complications arising from such a decision. Furthermore, the horrific impact on the training of practitioners and specialists will be overwhelming. Such an action is an irrational abuse of public power, and unlawful conduct in conflict with the Constitutional duties imposed on those delegated to exercise such power.

When a province fails to fulfil an executive obligation in terms of the Constitution or legislation, appropriate steps may be taken by the national executive to ensure its fulfillment. This could be achieved by issuing a directive to the provincial executive describing the extent of its failure to fulfil its obligations, and stating the steps necessary to address these, as set out in section 100(1)(a). Section 100(1)(b) allows for the national executive to assume responsibility for the relevant obligations to the extent necessary to maintain essential national standards or meet established minimum standards for the rendering of a service. It can be argued that it is time for the national executive to exercise section $100(1)(b)$, and take over the responsibility of healthcare delivery in provinces such as Gauteng, as it has done in North West. ${ }^{[18]}$

The healthcare crisis gripping the country, and some provinces in particular, is evidence again that while SA has one of the most laudable Constitutions globally, its implementation is riddled with impediments. This is further compounded by the impasse created by the legal constraints between national and provincial governments. Decision-makers impinge adversely on the rights of $84 \%$ of our country's patients, and shamefully disrespect our Constitution. Impeding access to healthcare impacts human dignity and disregards the self-worth of each individual. For healthcare to be nursed out of intensive care, urgent interventions, including exercising section 100(1)(b), are necessary. Medium- and long-term interventions must include addressing legal obstacles and leadership failures, and improving management skills. Furthermore, strikes and protests in the healthcare context must be dealt with appropriately, through relevant legal channels and via law enforcement.
Acknowledgements. None.

Author contributions. Equal contributions.

Funding. None.

Conflicts of interest. None.

1. ENCA. SA healthcare system on verge of collapse: Health Ombudsman. ENCA, 4 June 2018. http://www.enca.com/south-africa/watch-sa-healthcare-system-onverge-of-collapse-health-ombudsman (accessed 6June 2018).

2. Mkize V. Health minister outlines plan of action. News24, 10 June 2018. https:// www.news24.com/SouthAfrica/News/health-minister-outlines-plan-ofaction-20180609? (accessed11 June 2018)

3. Child C. Medical specialists crisis: 'If you don't fill these posts, the whole health structure will collapse'. TimesLive, 6 June 2018. https://www.timeslive.co.za/ news/south-africa/2018-06-06-medical-specialists-crisis-If-you-don't-fill-theseposts-the-whole-health-structure-will-collapse/ (accessed11 June 2018).

4. Masweneng K.'Patient dies during strike in Klerksdorp hospital' Sunday Times, 25 April 2018. https://www.timeslive.co.za/news/south-africa/2018-04-25-patientdies-during-strike-in-klerksdorp-hospital/ (accessed 4 June 2018).

5. Medical Brief. 'Mahikeng doctor defies strike violence to deliver babies' Medical Brief, 2 May 2018. https://www.medicalbrief.co.za/archives/mahikeng-doctordefies-strike-violence-deliver-babies/ (accessed 6 June 2018).

6. South Africa. Department of Health White Paper: National Health Insurance Policy: Towards Universal Health Coverage, 2017. http://www.health.gov.za/ index.php/component/phocadownload/category/383 (accessed 10 June 2018)

7. Vergunst R, Swart L, Mji G, Kritzinger J, Braathen SH. Beyond the checklist: Understanding rural health vulnerability in a South African context. Glob Health Action 2016;9(1):33272. http://doi.org/10.3402/gha.v9.33272

8. World Health Organization. Constitution of the World Health Organisation. Geneva: WHO, 1946. http://apps.who.int/gb/bd/PDF/bd47/EN/constitution-en. pdf?ua $=1$ (accessed 1 October 2017).

9. United Nations. The Universal Declaration of Human Rights. Geneva: UN, 1948. http:// www.un.org/en/universal-declaration-human-rights/ (accessed 1 October 2017).

10. United Nations. International Covenant on Economic, Social and Cultural Rights, Geneva: UN, 1976. http://www.pwescr.org/PWESCR_Handbook_on_ESCR.pdf (accessed 1 October 2017).

11. Organisation of African Unity. African Charter on Human and People's Rights. Banjul: OAU, 1986. https://hrnjuganda.org/wp-content/uploads/African-Charteron-Human-and-Peoples-Rights.pdf (accessed 1 October 2017).

12. United Nations, World Health Organization. The Right to Health. UN Fact Sheet No. 31. Geneva: UN, WHO, 2008. http://www.ohchr.org/Documents/Publications/ Factsheet31.pdf (accessed 1 October 2017).

13. Constitution of the Republic of South Africa, 1996. Chapter 2: Bill of Rights. https://www.gov.za/documents/constitution/chapter-2-bill-rights (accessed 1 October 2017).

14. South Africa. The National Health Act No 61 of 2003. https://www.gov.za/sites/ www.gov.za/files/a61-03.pdf (accessed 1 October 2017).

15. South Africa. The Patients' Rights Charter. Pretoria: HPCSA, 1999. http://www. hpcsa.co.za/downloads/conduct_ethics/rules/generic_ethical_rules/booklet_3_ patients rights charter.pdf (accessed 1 October 2017).

16. South Africa. Children's Act No. 38 of 2005. http://www.hpcsa.co.za/Uploads/ editor/UserFiles/downloads/legislations/acts/childrens_act_38_2005.pdf (accessed 10 June 2018).

17. Moseneke J. The Life Esidimeni Arbitration Report. http://www.saflii.org/images/ LifeEsidimeniArbitrationAward.pdf (accessed 11 June 2018).

18. Gerber J. Cabinet places North West Health Department under Administration. News24, 26 April 2018. https://www.news24.com/SouthAfrica/News/cabinetplaces-north-west-health-dept-under-administration-20180426 (accessed 10 June 2018).

Accepted 18 June 2018. 